\title{
DAKWAH DALAM PERSPEKTIF PARADIGMA TRADISIONALISME DAN REFORMISME
}

\author{
Abdul Hamid \\ Universitas Islam As-Syafi'iyah \\ Jln. Raya Jatiwaringin No. 12 Pondok Gede Jakarta Timur 13077 \\ Email: salamku82@yahoo.com
}

\begin{abstract}
Dakwah in the Paradigm of Traditionalism and Reformism. The paradigm and movement of dakwah are in the elements of the substance of the dakwah itself. They are more directed to cultural dialogue, intellectual and civilized dakwah. There are many movements that are in the name of Islam. Those forms of paradigm will not be discussed any furtherer here. However, the following two forms of Dakwah represent the diversity of the Islamic paradigm and dakwah movements. The traditionalists believe syari'a as the law of God that has been known and practiced since centuries ago and has been crystallized in some madhabs of fiqh. While the reformers oppose to taqlid and promote ijtihad to face contemporary issues. Although the reformers follow the concept of modernism and rationalism, however, they only examine the areas that are less obvious (zhanni) in law.
\end{abstract}

Keywords: Dakwah, Traditionalism, Reformism

Abstak: Dakwah dalam Perspektif Paradigma Tradisionalisme dan Reformisme. Dalam pemikiran dan gerakan dakwah ada dalam elemen-elemen substani dakwah itu sendiri, hanya ianya lebih mengarah kepada dialog budaya, intelektual dan dakwah peradaban. Dalam tubuh umat Islam, sebenarnya banyak gerakan-gerakan yang mengatasnamakan Islam. Semua bentukbentuk aliran-aliran paradigma tersebut, tidak akan dibahas di sini secara menyeluruh. Namun demikian, dua bentuk aliran dakwah berikut ini dianggap telah mewakili keragaman paradigma pemikiran dan gerakan dakwah. Kaum tradisionalis meyakini syari'ah sebagai hukum Tuhan yang telah dipahami dan dipraktekkan semenjak beberapa abad silam dan sudah terkristal dalam beberapa mazhab fiqh. Sementara aliran reformis menentang taqlid dan menggalakkan ijtihad dalam menghadapi persoalan-persoalan kontemporer. Meskipun menyamai modernisme yang mendukung konsep rasionalisme, namun ada perbedaannya karena aliran reformisme hanya berijtihad dalam bidang-bidang yang kurang jelas (zhanni) kedudukan hukumnya

Kata Kunci: Dakwah, tradisionalisme, reformisme 


\section{Pendahuluan}

Salah satu penyebab kegagalan Islam dewasa ini justru disebabkan oleh keterlenaan (keberhasilannya) yang gemilang di masa lalu. Baik karena keyakinan akan ajarannya yang sudah mutlak sempurna serta warisan budaya masa lalu yang amat kaya dan menakjubkan, maka seakan tidak ada lagi ruang bagi umat Islam dewasa ini untuk melakukan inovasi. Yang ada adalah melakukan konservasi, revitalisasi, dan kembali pada kaidah-kaidah lama yang telah diwariskan oleh zaman keemasan ketika itu. ${ }^{1}$

Kuatnya memory of the past yang kemudian menjadi semacam ideologi yang disakralkan, maka dunia Islam secara psikologis merasa memiliki dunia tersendiri, begitu juga pihak barat. Sikap ketertutupan ini pada hakekatnya menjadi pembatas untuk bisa melihat dan menerima realita dunia baru. Bahwa dunia pada abad lalu bukanlah dunia yang ada pada hari ini, itulah kenyataan yang harus diterima dengan sikap terbuka. Agama dan budaya lokal yang pada mulanya tumbuh secara isolatif, sekarang mau tidak mau harus berinteraksi dengan yang lain disaat pluralitas agama dan budaya tidak bisa lagi dibendung. ${ }^{2}$

Berbagai klaim eksklusifisme agama dan budaya sulit dipertahankan, bahkan gagasan nasionalisme klasik yang muncul oleh antagonisme politik, sekarang bergeser menjadi nasionalisme kosmopolitan. Sekarang ini, kehidupan sebuah bangsa bukan lagi dikawal dengan kekuatan senjata, melainkan dengan kemitraan dengan bangsa lain. Kedalam, yang dilakukan bukan lagi mobilisasi massa untuk berperang, melainkan memberi ruang partisipasi publik selebar mungkin untuk bersama-sama membangun peradaban. Islam memiliki potensi globalitas maupun lokalitas. Secara normatif, al-Qur'an sendiri menyatakan bahwa Islam sebagai rahmatan lil- 'alamin, ${ }^{3}$ merupakan pernyataan simbolik dari dimensi globalitas Islam, sementara diayat yang lain, al-Qur'an mengakui adanya pluralitas dan

${ }^{1}$ Dalam pandangan al-Qaradhawi kemorosotan umat Islam sekarang ini, itu karena disebabkan oleh adanya sifat kejumudan dalam diri umat Islam sendiri. Karena faktor kejumudan ini, al-Qaradhawi mengkritik habis-habisan suatu gerakan yang takut melakukan pembaruan dan stagnan kepada pemikiran para pengembannya. Gerakan tersebut lanjutnya, seakan-akan sebuah wahyu dari langit atau perkataan orang maksum dari perbuatan dosa, sehingga kita takut untuk mengadakan perubahan yang lebih komprehensif dan efisien. Padahal lanjutnya, pembaruan gerakan Islam sudah merupakan aturan yang telah ditetapkan oleh syar'i. Baca Al-Qaradhawi, Aulawiyâtulharakâtil-islam Fî̀ Marhalatil-qadîmah, (dalam bentuk Maktabatusy-syâmilah), h. 6

${ }^{2}$ Komaruddin Hidayat, Wahyu di Langit Wahyu di Bumi, (Jakarta: Paramadina, 2003), h. 31

${ }^{3}$ QS. Al-Anbiya : 107 
lokalitas kesukuan (etnisitas) maupun kebangsaan (nasionalitas). ${ }^{4}$

Memandang wajah Islam yang berdimensi universal sekaligus partikular lokal dan temporal, secara normatif-teologis pada hakikatnya, bukanlah merupakan sebuah problem ketika Islam harus berdialektika dengan paradigma paradoksal di atas (kecenderungan global sekaligus lokal). Hanya saja yang menjadi persoalan di sini adalah sejauh mana batas wilayah keberagamaan Islam yang bersifat global (universal) serta lokal dan temporal itu? Di sini bisa saja muncul pandangan yang kontroversial dikalangan umat. Tetapi yang pasti, di dalam Islam, peluang untuk membangun sebuah paradigma gerakan, lebih-lebih berwajah lokal sangatlah dimungkinkan. Tafsiran tentang ini bisa bersifat plural tentunya, tergantung pada ruang historis yang berkembang maupun para perumus gerakan Islam itu sendiri. Toh, setiap ruang dan zaman pasti memiliki pola pemikiran yang berbeda pula (Islam shalihun li kulli zaman wa makan). Maka di era globalisasi sekarang ini dibarengi dengan munculnya berbagai kecenderungan lokalitas yang ada, umat dituntut untuk terus berijtihad. Iqbal menyatakan bahwa ijtihad merupakan prinsip gerak dalam struktur pemikiran Islam dengan secara maksimal menggerakkan berbagai potensialitas yang dimiliki. ${ }^{5}$

Dalam konteks ini, norma-norma Islam yang universal barangkali tidak terlalu banyak dipermasalahkan, karena secara normatif telah banyak tersedia di dalam kitab suci maupun hadis Nabi serta khazanah ulama klasik lainnya. Yang menjadi sangat problematis saat ini adalah dimensi harakah Islam yang berwajah lokal yang harus dirumuskan oleh para ahli, baik gerakan lokal yang terkait dengan aliran aqidah agar tidak terjebak dengan sinkretisme maupun aliran fiqh dalam arti luas, yakni fiqh lingkungan, fiqh seni, kebudayaan, dan peradaban, fiqh kontemporer, dan lain-lain.

Robert N. Bellah mengungkapkan betapa Islam dengan melalui Muhammad saw telah terbukti sukses, bahkan membangun peradaban yang justru dimulai dari tengah-tengah padang pasir yang tandus dan gersang serta dari kerumunan tribal society ditengah pluralitas masyarakat Mekkah di zamannya. Kesuksesan Muhammad tidaklah diukur dari kualitas yang dicapainya, lebih dari itu, adalah tingkat kualitas moral peradaban yang diwariskannya. ${ }^{6}$

\footnotetext{
${ }^{4}$ QS. Al-Hujurat :13

${ }^{5}$ Mohammad Iqbal, The Recontruction of Relegius Thought in Islam, (Lahore : Ashraf, 1982), h. 146

${ }^{6}$ Robert N Bellah, Beyond Belief, Essay on Religion in a Post-Tradisional Word, (New York: Harper and Row, 1976), h. 50-51
} 
Dalam sejarah peradaban Islam, banyak sekali warisan peradaban yang pada hakikatnya tidak murni dari warisan Islam. Tetapi, sebaliknya, justru banyak mengadopsi dari warisan luar Islam. Sebagai salah satu contoh, bentuk menara mesjid yang kini menjadi ciri umum bangunan mesjid diseluruh dunia Islam merupakan salah satu bukti hasil interaksi Islam dengan kekayaan budaya lokal. ${ }^{7}$

Ini berarti bahwa dalam perjalanan historisitasnya, Islam tetap bisa bersinergi dengan kekayaan peradaban dunia sepanjang secara teologis tidak lari dari komitmen imani sebagaimana yang telah digariskan oleh Islam. Untuk zaman ini, bahkan di masa-masa mendatang, agama Islam bersama agama atau paham lain harus bisa menjalin bahkan menyatu dalam memperkaya mozaik warisan kultural dunia, sehingga dimensi ketunggalan rasa kemanusiaan serta laku dakwah dan gerakan menjadi media komunikasi keharmonisan interaktif dan dialektik antar hubungan sesama umat manusia di dunia. Pandangan lokalisasi Islam ini, merupakan pemikiran lanjut dari empirisme Islam. Menurut Iqbal, secara normatif, alQur'an lebih mementingkan tindakan nyata (deed) ketimbang semata-mata gagasan idealistik rasionalistik. ${ }^{8}$

Kelemahan para pemikir Islam klasik lanjut Iqbal, karena mereka terlalu memaksakan logika deduktif dalam memahami al-Qur'an, sehingga berakibat pada kekaburan pemahaman. Pandangan tokoh Islam yang berwawasan empirik ini, paling tidak dapat dijadikan acuan tentang pentingnya pembumian ajaran Islam melalui gerakan atau aliran-aliran murni Islam. ${ }^{9}$

Pada dataran empiris, sesuai dengan fenomena dan tantangan multikultural yang ada, yang menjadi problem buat kita adalah, bagaimanakah upaya lokalisasi dan kulturalisasi Islam sehingga hal demikian kelak mampu dijadikan media dakwah sebagai perekat sosial pada tingkat wacana lokal tanpa harus mereduksi dimensi universalitas Islam itu sendiri. Warna dakwah semacam ini, tentu akan menjadi cikal bakal lahirnya paradigma (gerakan aliran-aliran dakwah) atau mazhab-mazhab baru dalam bentuk pemikiran. Yang secara kontras akan berbeda dengan sistem teologis Islam

${ }^{7}$ Nurcholish Madjid, Islam Doktrin dan Peradaban, (Jakarta: Paramadina, 1992), h. 445

${ }^{8}$ Mohammad Iqbal,, h. IV

${ }^{9}$ Amin Abdulllah, Respons Kreatif Muhammadiyah Dalam Menghadapi Dinamika Kontemporer, dalam M. Toyyibi (ed.), Sinergi Agama dan Budaya Lokal, (Solo: Muhammadiyah University Press, 2002), h. 20 
yang subtansialis dan kulturalis. Namun, bentuk praktikalnya dalam pemikiran dan gerakan dakwah ada dalam elemen-elemen substani dakwah itu sendiri, hanya ianya lebih mengarah kepada dialog budaya, intelektual dan dakwah peradaban. Dalam tubuh umat Islam, sebenarnya banyak gerakan-gerakan yang mengatasnamakan Islam dan sangat penting bagi kita untuk mengetahuinya. Semua bentuk-bentuk aliran-aliran paradigma tersebut, tidak akan dibahas di sini secara menyeluruh. Namun demikian, dua bentuk aliran dakwah berikut ini dianggap telah mewakili keragaman paradigma pemikiran dan gerakan dakwah. ${ }^{10}$

\section{Aliran Dakwah Paradigma Tradisionalisme}

Ketika berbicara mengenai tradisionalisme khususnya dilingkungan masyarakat Islam, maka yang terbayang adalah sebuah gambaran mengenai masyarakat yang terbelakang, kolot, dan masyarakat yang anti perubahan (anti progresivitas), konservatif (staid approach), dan diliputi oleh sikap taqlid. Mereka adalah kelompok yang membaca atau terlalu mendewakan "kitab kuning", termasuk didalamnya karya al-Ghazali dan ulama fiqh klasik, serta tokoh-tokoh sufi pada zaman pertengahan Islam. ${ }^{11}$

Tradisional merupakan terma untuk sesuatu yang irrational, berpandangan tidak ilmiah, atau lawan dari segala bentuk kemoderenan. Tradisionalisme dianggap sebagai aliran yang berpegang teguh pada keaslian Agama, melalui penafsiran terhadap kitab suci secara rigid dan literalis. ${ }^{12}$ Dari segi etimologis, tradisional berarti kecenderungan untuk melakukan sesuatu yang telah dilakukan oleh pendahulu, dan memandang masa lampau sebagai otoritas dari segala bentuk yang telah mapan. ${ }^{13}$ Menurut Achmad Jainuri, kaum tradisionalis adalah mereka yang pada umumnya diidentikkan dengan ekspresi Islam lokal, serta kaum elit kultur tradisional yang tidak tertarik dengan perubahan dalam pemikiran serta praktikuler Islam. ${ }^{14}$

${ }^{10}$ Untuk menambah wawasan para pembaca yang budiman, silahkan lihat juga Filsafat Dakwah; Rekayasa Membangun Agama dan Peradaban Islam, karangan Dr. A. Ilyas Ismail, MA dan Prio Hotman, MA. Terbitan Prenada Media Kencana Press, 2011, Cet. ke-1.

${ }^{11}$ Munir Mulkhan, Islam Murni dalam Masyarakat Petani (Yogyakarta: Yayasan Bentang Budaya, 2000), h. 2

${ }^{12}$ Fundamentalis", dalam The Oxford English Dictionary, 1988.

${ }^{13}$ Andrew Rippin, Muslim, 6.

${ }^{14}$ Achmad Jainuri, Orientasi Ideologi Gerakan Islam (Surabaya: LPAM, 2004), h. 68. 
Sementara itu, tradisionalisme adalah paham yang berdasar pada tradisi dan merupakan lawan dari modernisme, liberalisme, radikalisme, dan fundamentalisme. ${ }^{15}$ Berdasarkan pada pemahaman terhadap tradisi di atas, maka tradisionalisme adalah bentuk pemikiran atau keyakinan yang berpegang pada ikatan masa lampau dan sudah dipraktekkan oleh komunitas Agama. ${ }^{16}$

Dalam pengertian konservatif, tradisionalisme seperti kata Karl Mannheim, "a tendency to cling to vegetative patterns, to old ways of life. It is a reaction against deliberate reformingtendencies and characterized by almost fear of innovation". ${ }^{17}$ (adalah suatu kecenderungan yang sangat kuat untuk kembali kepada kehidupan lampau (salafusshalih). Hal ini, tentunya merupakan sesuatu yang kontraversi dengan perubahan dan perkembangan zaman).

Pendapat Mannhein relative sejalan dengan uraian Hisham Sharabi:

The traditionalism of the late nineteenth century was essentially reactionary in character. Its more articulate protagonists are what we have labeled the "conservative" intellectuals. The basic orientation of this traditionalism was historicism to use the term in a purely descriptive sense: that is, derive its inspiration and strength from a historically evolved tradition and in its intellectual attitude always assumed a backward looking stance. For the traditionalist, the past, rather than the future, was the locus of the Golden Age. The past was restorable and one day would be restored. Conservative traditionalist thought; though it may not whole heartedly espoused the statusquo, did not repudiate it. As the only concrete reality, the established order represented continuity and the only link with the past; it constituted the starting point of revival land the only basis on which to resist the European threat. ${ }^{18}$ (Para penganut paham tradisionalisme pada akhir abad kesembilan belas pada dasarnya memiliki karakter keras dan kaku. Mereka lebih dikenal dengan sikap konservatifnya dalam bidang intelektual. Orientasi dasar dari tradisionalisme ini adalah historisisme dengan menggunakan istilah dalam

\footnotetext{
${ }^{15}$ Noah Webstar, Webstar new International Dictionary of the English Language Unabridged (Massachusetts, USA: G\&C, 1966), 2422.

${ }^{16}$ Noah Webstar, Webstar new International, h. 2442.

${ }^{17}$ Karl Mannheim, "Conservative Though", dalam K. Mannheim, Essays on Sociology and Social Psycology, (London : Rautledge \& Kegan Paul, 1966), h. 95-96.

${ }^{18}$ Hisham Sharabi, Arab Intellectuals and the West : The Formative Years 1875-1914, (Baltimore \& London : The John Hopkins University Press, 1970), h. 6
} 
arti murni deskriptif, yaitu berdasarkan inspirasi dan kekuatan tradisi historis dalam melihat perkembangan intelektualnya dan selalu mengambil keputusan para pendahulunya dalam memutuskan berbagai halyang bersifat keagamaan. Tradisionalis selalu konservatif dalam berpikir, meskipun itu tidak rasional atau bahkan bertentangan dengan hati nuraninya. Sebagai realitas konkret saja, untuk melawan orang-orang barat harus kembali kepada ajaran agama yang asli).

Sesuai dengan pengertian tersbut, tradisionalisme melihat sejarah hanya sebagai sumber inspirasi atau sesuatu yang harus diperhatikan. Karena itu para pendukungnya dikatakan bersikap negatif terhadap pembaruan dan perubahan. Menurut Roger Garaudy, golongan tradisonalis menganggap kemunduran umat Islam di sebabkan mereka menjauhkan diri dari ajaran generasi lalu, memutuskan ikatan terhadap tradisi mereka, dan mengikuti godaan setan dari Barat. Bertolak dari pandangan ini, mereka menyimpan Islam dalam suatu benteng tanpa jendela dan pintu keluar, tanpa ruangan terbuka kearah langit, serta mempertahankan seluruh tradisi tanpa membedakan ajaran Islam dari campuran dan endapan yang tertinggal di bawah pengaruh masyarakat beraneka ragam yang serupa dengan ajaran al-Qur'an. ${ }^{19}$

Mengapa golongan tradisionalis bersikap tertutup sedemikian rupa?, sebab, mereka menyamakan tradisionalisme dengan ortodoksi dalam pengertian asli, benar, dan tepat tanpa penyelewengan dan pemalsuan, baik dari segi doktin maupun praktik, sebagaimana digunakan dalam rangkaian Orthodox Theology. Jadi, karena keyakinan itulah mereka bersikap statis dan konservatif. $^{20}$

Di bidang pemikiran Islam, tradisionalisme adalah suatu ajaran yang berpegang pada Sunnah Nabi, yang diikuti oleh para Sahabat dan secara keyakinan telah dipraktekkan oleh komunitas Muslim. ${ }^{21}$ Kaum tradisionalis di Indonesia adalah mereka yang konsisten dalam berpegang teguh pada mata rantai sejarah serta pemikiran ulama-ulama terdahulu dalam perilaku keberagamaannya. Konkritnya, memegang dan mengembangkan ajaran fiqh scholastik madzhab empat. ${ }^{22}$

\footnotetext{
${ }^{19}$ Roger Garaudy, Janji-janji Islam, terj. (Jakarta : Bulan Bintang, 1982), h. 223-224

${ }^{20}$ Muhd. Uthman el-Muhammady, Memahami Islam, (Kota Baharu : Pustaka Aman Press, 1977), h. 182

${ }^{21}$ Daniel Brown, Rethinking Tradition, h. 2.

${ }^{22}$ Seyyed Hossein Nasr mencatat salah atu kriteria pola keagamaan tradisional adalah
} 
Kaum tradisionalis meyakini syari'ah sebagai hukum Tuhan yang telah dipahami dan dipraktekkan semenjak beberapa abad silam dan sudah terkristal dalam beberapa mazhab fiqh. Dalam bahasa Fazlur Rahman, mereka lebih cenderung memahami syari'ah sebagaimana yang telah diperaktekkan oleh ulama terdahulu. ${ }^{23}$ Mereka menerima prinsip ijtihad, akan tetapi harus sesuai dengan prinsip-prinsip hukum tradisional seperti qiyâs, ijmâ' dan istibsân. ${ }^{24}$

Dalam masalah tarekat mereka menganggapnya sebagai dimensi terdalam dari ajaran Islam. Dalam masalah tarekat ini mereka merujuk kepada Imam al-Ghazali untuk dijadikan sebagai tokoh sentral, yang muncul pada abad ke-12, seperti ajaran yang disampaikan oleh al-Ghazali. ${ }^{25}$

Di Indonesia seperti yang dikatakan Howard Federspiel, tradisionalisme dipandang sebagai paham yang mempertahankan nilai-nilai yang telah mapan dikalangan umat Islam terutama penganut mazhab Syafi'i. Kelompok ini muncul sebagai bentuk perlawanan terhadap pandanganpandangan kaum modernis. Sementara terma modernis menunjukkan pada kelompok yang merasionalkan segala bidang kehidupan, termasuk agama, pengetahuan dan teknologi. Kelompok ini, muncul pada abad ke-20, yang menyerukan reformasi bidang agama dan menjadikan Islam sebagai senjata dalam melawan modernisasi ditengah-tengah masyarakat muslim. ${ }^{26}$ Kelompok ini di Indonesia sering digolongkan ke dalam organisasi sosial keagamaan seperti NU. ${ }^{27}$

Golongan tradisionalis banyak menghiraukan soal-soal ibdah belaka. Bagi mereka Islam seakan sama dengan fiqh, dan dalam hubungan ini mereka mengakui taqlid dan menolak ijtihad. Sikap ini, sering menyebabkan mereka menjadi patuh buta, sebab imam madzhab fiqh atau kyai dianggap ma'sum, bebas dari kesalahan. Dalam situasi seperti itu, Islam dan tafsiran

\footnotetext{
digunakannya konsep silsilah; mata rantai kehidupan dan pemikiran dalam dunia kaum tradisional untuk sampai pada sumber ajaran. Lihat Seyyed Hossein Nasr, Tradisional Islam, h. 13.

${ }^{23}$ Fazlur Rahman, "Islamic Modernism; Its Scope, Method, and Alternative", International Journal of Middle East Studies (1970), h. 317-332

${ }^{24}$ Fazlur Rahman, "Islamic Modernism, h. 317-332

${ }^{25}$ Fazlur Rahman, "Islamic Modernism, h. 317-332

${ }^{26}$ Ronald Alan Lukens Bull, A Peaceful Jihad 125-126

${ }^{27}$ Organisasi ini telah berdiri sejak tahun 1926 di Surabaya, oleh beberapa ulama pengasuh pesantren, di antaranya K.H. Hasyim Asy'ari (Tebu Ireng) dan K. Wahab Hasbullah (Tambak Beras). Baca Ronald Alan Lukens Bull, A Peaceful Jihad, 124. Lihat juga Greg Barton (ed), Tradisionalisme Radikan;Persinggungan Nahdatul Ulama' Negara, ter. Ahmad Suaedy (Yogyakarta;LKiS, 1997), h. 220
} 
tentangnya merupakan monopoli kyai belaka, sehingga fatwa kyai dianggap mutlak, final dan tidak dapat dipertanyakan lagi. ${ }^{28}$

Dalam konteks sosial-budaya, unsur-unsur yang terdapat pada Islam tradisional, khususnya di Indonesia sangat identik dengan adanya lembaga pesantren, peranan dan kepribadian kyai dengan kharismatiknya. Basis masa kaum tradisionalis semacam ini, pada umumnya berada di pedesaan. Begitu lekatnya Islam tradisionalis dengan kalangan pedesaan, sampai-sampai dikatakan bahwa Islam tradionalis adalah Islam pedesaan. ${ }^{29}$ Peristilahan ini, secara religi bersifat kultural, namun sinkretik.. ${ }^{30}$ Meskipun untuk saat ini banyak kaum tradisionalis yang kontroversial dengan paham konservatif,. Namun, peran warna konservatifme sangatlah kuat terutama ditingkat lokal. ${ }^{31}$

Pada satu segi, aliran tradisionalisme memang mencoba mempertahankan tradisi asli keagamaan. Namun, keaslian dalam konteks ini lebih merujuk kepada ajaran-ajaran para ulama mazhabiyah atau sikap taqlid kepada empat imam mazhab. Jika ditelusuri ke belakang ternyata taqlid bermula pada abad ke-4 H, ketika Bani Abbasiyah didominasi oleh bangsabangsa asing dan diperburuk dengan kejatuhannya ditangan mongol pada tahun $1258 \mathrm{M}^{32}$

Muhammad Kamal Hassan dalam konteks ini menegaskan, bahwa golongan tradisonalis, "tend to restrict the role of ijtihad in preference to, and out of deference, for the established opinions of the masters of the schools of Islamic jurisprudene" (yaitu, adanya kecenderungan untuk membatasi ruang ijtihad dalam mengambil suatu keputusan demi menjaga rasa hormat kepada para pendahulu). ${ }^{33}$

Pada dasanya, sikap taqlid dan pembekuan ijtihad terjadi dalam fikih dengan merujuk pada karya ulama mazhabiyah atau yang bertaqlid kepada

${ }^{28}$ Deliar Noer, Gerakan Modern, 320-321.

${ }^{29}$ Kacung Marijan, Quo Vadis NU Setelah Kembali ke Khittah 1926 (Jakarta: Penerbit Erlangga, 1992), h. 38.

${ }^{30}$ Kacung Marijan, Quo Vadis NU, h. 38

${ }^{31}$ Zainuddin Maliki, Agama Priyayi (Yogyakarta: Pustaka Marwa, 2004), h. 41.

${ }^{32}$ Muhammad al-Hudari, Tarikh Tasyri' Islami, terj. (tt : Penerbit Rajamurah al-Qanaah, 1980) h. 519-523. Lihat juga Abdul Wahab Kallaf, Ringkasan Sejarah Perundangan Islam, terj. (kota Bharu: Pustaka Aman Press, 1971), h. 149-156

${ }^{33}$ Prof. Muhammad Kamal Hasan, Muslim Intellectual Responses to New Order Modernization in Indonesia, (Kuala Lumpur : Dewan Bahasa dan Pustaka, 1980), h. XI 
mereka, bukan karya atau pemikiran para imam mujtahid itu sendiri. Karya-karya ini muncul dalam bentuk syarah (penjelasan isi), hasyiah (catatan kaki), atau hamsy (catatan pinggir) yang kandungannya lebih sulit dipahami dari pada kitab induknya. ${ }^{34}$ Bahkan, bukan hanya dalam fikih, dalam tauhid juga ditemukan hal yang sama. Yang diikuti bukan ajaran asli para penggagasnya, melainkan kitab-kitab syarah (penjelasan) yang ditulis oleh ulama muta'akhirin. ${ }^{35}$ Begitu juga dalam bidang tasawuf yang banyak tumbuh sesudah Baghdad jatuh. ${ }^{36}$

Inilah beberpa ciri utama aliran tradisionalis sebagaimana dipahami dan diterima oleh banyak orang. Dalam perkembangannya, konsep tradisionalisme telah dipengaruhi unsur falsafah dan aliran metafisika Barat. Di antara tokoh-tokoh pemikir tradisionalis ialah Sayyid Hossein Nasr, Martin Lings dan Hamid Algar. Melalui sentuhan mereka, konsep terdisionalisme memperoleh wajah baru. Sebagai gerakan intelektual baru dan elitis, pandangan mereka memang didasarkan pada hujah-hujah atau alasan-alasan yang cukup meyakinkan. Walaupun bertolak dari warisan peradaban Islam, pemikiran mereka banyak dipengaruhi oleh falsafah dan peradaban asing. ${ }^{37}$

\section{Aliran Dakwah Paradigma Reformisme}

Ciri utamanya ialah semangat puritanisme, yaitu penekanan kepada ajaran Islam yang murni (pristine). Ada semacam persamaan dengan aliran tradisionalisme yang menekankan ortodoksi atau keaslian ajaran Islam. Bertolak dari semangat puritanisme, aliran reformis sangat menekankan ishlah dan tajdid. Ishlah merupakan upaya memperbaiki atau membersihkan Islam dari pemalsuan dan penyelewengan..$^{38}$ sedangkan tajdid adalah

\footnotetext{
${ }^{34}$ Muhammad al-Hudari, op. cit., h. 579-586. Lihat juga Ahmad Shalaby, Masyarakat Islam, terj. (Singapura: Pustaka Nasional, 1966), h. 339-340

35 W.M Watt, Islamic Philosophy and Theology, (Edinburgh : Edinburgh University Press, 1977), h. 149

${ }^{36}$ Lihat J. Spencer Trimingham, Sufi Orders in Islam, (New York : Oxford University Press, 1973)

${ }^{37}$ Baca Sarah Stroumsa, Para Pemikir Bebas Islam, terj. (Yogyakarta : LKIS Yogyakarta, 2006), Cet. ke-1. Al-Zastrouw Ng, Gerakan Islam Sembolik, (Yogyakarta : LKIS Yogyakarta, 2006), Cet. ke-1. John Cooper. (et. al), Pemikiran Islam, terj. (I.B. TAURIS \& Co. Ltd, London. Indonesian translation oleh Erlangga, 2002)

${ }^{38}$ Hasan Said Karmi, al-Manar and English-Arabic Dictionary, (Bairut : Longman Libraise Du Liban, 1970), h. 567
} 
memperbarui atau menyegarkan kembali paham dan komitmen terhadap ajaran-ajaran agama sesuai dengan tuntunan zaman. ${ }^{39}$

Tajdid berkaitan erat dengan ijtihad, bahkan tidak dapat dipisahkan sehingga saling melengkapi. Secara terminologi, ijtihad berarti usaha serius untuk menyimpulkan hukum-hukum syara' berlandaskan kaidah tertentu dalam menghadapi persoalan-persoalan baru yang tidak jelas hukumnya dalam nash-nash al-Qur'an dan sunnah atau ijma..$^{40}$

Dalam konteks inilah timbul perbedaan antara reformisme dan tradisionalisme karena aliran reformis menentang taqlid dan menggalakkan ijtihad dalam menghadapi persoalan-persoalan kontemporer. ${ }^{41}$ Meskipun menyamai modernisme yang mendukung konsep rasionalisme, namun ada perbedaannya karena aliran reformisme hanya berijtihad dalam bidangbidang yang kurang jelas (zhanni) kedudukan hukumnya. ${ }^{42}$

Barangkali karena beberapa persamaan di samping perbedaan dengan tradisionalisme dan modernisme itulah sebagian sarjana menganggap reformis merupakan sentesis atau pertengahan di antara keduanya. ${ }^{43}$ Berdasarkan difinisi dari ciri-ciri tersebut, maka reformasi merupakan aliran pemikiran distingtif (tersendiri) dalam Islam. Namun para sarjana berbeda pendapat tentang posisi aliran ini. Pihak pertama mencoba menyamakan pangertian reformisme dengan modernisme, seolah-olah keduanya saling melengkapi. Jelasnya, modernisme Islam tidak lain merupakan reformisme Islam. ${ }^{44}$

Bila pihak pertama tidak dapat membedakan reformisme dengan modernisme, maka pihak kedua tidak dapat membedakan reformisme

\footnotetext{
${ }^{39}$ Abdul Ghani Hj. Shamsuddin, Tajdid dalam Pendidikan dan Masyarakat, (Kuala Lumpur: Persatuan Ulama Malaysia, 1989), h. 11

${ }^{40} \mathrm{Al}$-Qaradhawi, Ijtihad dan Syari'ah Islam, terj. (Jakarta : Bulan Bintang, 1989), h. 147-153

${ }^{41}$ Muhammad Kamal Hassan, loc. cit.

${ }^{42}$ Sedangkan aliran modernisme dengan prinsip berpegang pada akal "berijtihad" tanpa batas hingga memasuki hal-hal yang sudah jelas (qat'iyyah) hukumnya. Disinilah sumber penentangan Dr. Mahmud Thahhan terhadap usaha tajdid ushul fikih yang digelar Dr. Hassan at-Turabi karena dianggap terlalu perpedoman pada akal. Baca Mahmud Thahhan, Pembaruan Pemikiran Islam Sebuah Upaya Tipu Daya Belajar dari Kasus Sudan, terj. (Jakarta : Amarpress, 1987)

${ }^{43}$ Hisham Sharabi, op. cit. lihat juga M. A. Zaki Badawi, The Reformismof Egypt (London: Croom Helm Ltd. 1978), h. 149. Lihat juga Sami Abdullah Kaloti, The Reformation of Islam and The Impact of Jamaluddin al-Afghani and Muhammad Abduh on Islamic Education. Desertasi Ph. D., Marquettes University, 1974.

${ }^{44}$ H.AR. Gibb, Aliran-aliran Modern Dalam Islam, terj. (Jakarta : Rajawali Press, 19990),
} 
Islam dengan reformisme protestan. Menurut mereka, istilah reformisme mengandung pengertian kelabu karena mengingatkan orang pada gerakan reformasi yang melahirkan aliran Protestan di bawah panji-panji gerakan Martin Luther. Sebagai alternatif, mereka menyarankan penggunaan kata Ishlah atau tajdid, karena lebih berkonotasi baik dan murni. ${ }^{45}$

Pihak ketiga menolak sama sekali keberadaan aliran reformasi. Bagi Sayid Hossein Nasr khususnya, keberadaan golongan ini, lebih banyak dibesar-besarkan oleh golongan orientalis. Sifat-sifatnya tidak jelas. Pada satu sisi dianggap sebagai "a truncated form of Islam", atau " pseudotraditional", atau "counter traditional". Dan di sisi lain sebagai "accept some of the most basic aspects of modernism" ${ }^{46}$

Di era modern, reformasi menurut Lapidus harus dirujuk kepada pengalaman sejarah Barat sejak timbulnya zaman modern. ${ }^{47}$ Namun dalam Islam menurutnya, reformisme adalah pengalaman sejarah umat Islam sendiri yang jauh sebelum dipengaruhi kekuasaan Barat yang membawa gejala modernisme. Abad pertumbuhan reformisme Islam itu ialah abad ke-17 dan 18 M., dengan merujuk peranan Muhammad bin Abdul Wahab (17031787). Sebenarnya, sejarah reformisme Islam jauh lebih awal dari itu, dengan kemunculan Ibnu Taimiyah (1263-1328) sebagaimana dikatakan oleh Ismail al-Faruqi "the first and greatest muslim reformer" (pembaruan paling besar dan utama terdapat di era muslim).$^{48}$ Malah, jika didasrkan pada pendapat yang lebih logis, gerakan reformis Islam sebenarnya dipelopori oleh Khalifah Umar bin Abdul Aziz (717-720) sejak abad ke-8 M. ${ }^{49}$

Muhammad al-Bahi berpendapat, bahwa reformasi Islam mempunyai sisi positif dan negatif. Reformasi bukan merupakan usaha intelektual untuk menundukkan Islam terhadap pemikiran asing. Ia berbeda dengan gerakan-gerakan keagamaan lain yang bersandar pada apologi terhadap

${ }^{45}$ Wan Muhammad bin Wan Muhammad Ali, op. cit., h. 31-32. Lihat juga Rifyal Ka’bah, (et. al), Reaktualisasi Ajaran Islam: Pembaruan Agama Visi Modernis dan Visi Salaf, (Jkarata: Penerbit Minaret, 1987).

${ }^{46}$ Sayis Houssein Nasr, Traditional Islam in The Modern World, (Kuala Lumpur: Foundation for Traditional Studies, 1988), h. 12-19

${ }^{47}$ Prof. Ira M. Lapidus, A History of Islamic Societes (Cambridge: Cambridge University Press, 1988), h. 560-561

${ }^{48}$ Prof. Ismail al-Faruqi, Islam, (Niles: Argus Communications, 1979), h. 78

${ }^{49}$ Abul A'la al-Maududi, A Short History of the Revivalist Movement in Islam, (Lahore: Islamic Publications Ltd., 1979), h. 45-50. Abu Hassan an-Nadwi, Saviours of Islamic Spirit, vol. 1, (Lucknow: Academiy of Islamic Research \& Publications, 1976), 
Islam atau penyederhanaan ajaran Islam dan mendekatkannnya kepada intelektualisme universal. Ia juga berbeda dengan usaha-usaha menfsirkan agama secara khusus, yang mengharuskan pemakaian salah satu mazhab fikih atau ilmu kalam. Apa yang dimaksud dengan reformasi, ialah usaha mengungkapkan nilai-nilai Islam yang paling esensial, dengan menjelaskan hal-hal yang berkaitan erat dengan Islam yang disalahartikan dan salahtafsirkan. Reformasi Islam ialah suatu pemikiran dan sistem berdasarkan kritik konstruktif dan hanya mengakui satu nilai, yaitu nilai Islam untuk menuntun umat manusia. ${ }^{50}$

\section{Penutup}

Jihad atau perjuangan pada dasarnya adalah pengerahan secara maksimal seluruh daya dan upaya untuk bersungguh-sungguh menghancurkan dan mencegah timbulnya berbagai bentuk kesesatan, kejahatan, dan kezaliman yang dibuat oleh musuh-musuh dalam bentuk manusia ingkar, setan yang menyesatkan, maupun hawa nafsu.

Dalam pandangan al-Qaradhawi, makna jihad terbagi ke dalam empat pengertian, pertama, jihad bermakna al-qital, yaitu jihad yang menggunakan senjata untuk menghadapi musuh. Kedua, jihad bermakna al-harb, yaitu perang dalam bentuk ideologi, kebudayaan, ekonomi, revolusi, elektronik, dan lain sebagainya. Ketiga, jihad dalam bentuk alunf (kekerasan), yaitu jihad menjadikan kekerasan sebagai cara untuk melakukan perubahan. Cara seperti ini sangat dibenci oleh Islam karena Islam tidak menyukai kekerasan. Keempat, jihad dalam arti al-irhab, yaitu jihad yang tidak disyariatkan walau pun tujuannya untuk menegakan agama, karena hanya membuat nama Islam sebagai agama teroris.

Dimasa kenabian, perjuangan untuk menegakkan Islam dan mengangkat kejayaan umat Islam terus dilakukan dalam upaya menyampaikan risalah Ilahiyah dan menyeru kepada manusia akan datangnya dua pembalasan yaitu al-Jannah bagi yang menerima da'wah Rasulullah, sebaliknya azab jahannam bagi yang mengingkarinya.

Dalam pandangan Sayyid Qutub perjuang (jihad) dimaksudkan untuk mewujudkan kebahagiaan dan kesejahteraan hidup di dunia dan di akhirat,

${ }^{50}$ Dr. Muhammad al-bahi, Pemikiran Islam Modern dan Hubungannya dengan Imperealisme barat, terj. (Jakarta : Pustaka Panjimas, 1986), h. 258-259 
dengan menyampaikan nilai-nilai yang dapat mendatangkan kebahagiaan sesuai dengan bidangnya masing-masing.

Seorang pejuang dengan jiwa spiritual akan selalu berusaha meningkatkan kesejahteraan hidupnya melalui perjuangan. Gerakan perjuangan ini dilakukan terus menerus dan terencana dengan memanfaatkan sumber daya manusia dan sumber daya alam, juga jasa ilmu pengetahuan dan teknologi.

Semoga kajian tulisan paradigma perjuangan ini dapat memberi khazanah baru bagi wacana keislaman, khususnya dalam hal dakwah, serta berusaha untuk mengaplikasikannya demi menggapai keberhasilan dalam segala aspek kehidupan di dunia dan di akhirat. Wallahu a’lam bissawab.

\section{Pustaka Acuan}

Al-Bahi, Muhammad, Dr., Pemikiran Islam Modern dan Hubungannya dengan Imperealisme barat, terj. (Jakarta : Pustaka Panjimas, 1986)

Al-Faruqi, Ismail, Prof, Islam, (Niles : Argus Communications, 1979)

Al-Hudari, Muhammad, Tarikh Tasyri' Islami, terj. (tt : Penerbit Rajamurah al-Qanaah, 1980)

Al-Maududi, Abul A'la, A Short History of the Revivalist Movement in Islam, (Lahore : Islamic Publications Ltd., 1979)

Al-Qaradhawi, Yususf, Aulawiyâtul-harakâtil-islam Fî Marhalatil-qadîmah, (dalam bentuk Maktabatusy-syâmilah)

, Ijtihad dan Syariah Islam, terj. (Jakarta : Bulan Bintang, 1989) , Fikih Jihad, (Bandung : PT Mizan Pustaka, 2010), Cet. ke- 1 , Islam dan Globalisasi Dunia, (Jakarta Timur: Pustaka Al-Kautsar : 2001), cet ke-1

Alisyahbana, A. Takdir, Antropologi Baru, (Jakarta: Dian Rakyat, 1986) Al-Zastrouw Ng, Gerakan Islam Sembolik, (Yogyakarta : LKIS Yogyakarta, 2006), Cet. ke-1.

An-Nadwi, Abu Hassan, Saviours of Islamic Spirit, vol. 1, (Lucknow : Academiy of Islamic Research \& Publications, 1976)

Azizy, A. Qodri, Melawan Globalisasi, (Yogyakarta : Pustaka Pelajar, 2004) Barton, Greg, (ed), Tradisionalisme Radikan;Persinggungan Nahdatul Ulama' Negara, ter. Ahmad Suaedy (Yogyakarta;LKiS, 1997) 
Badawi, M. A. Zaki, The Reformismof Egypt (London: Croom Helm Ltd. 1978)

Baqi, Muhammad Fuad Abdul, Al-Mu'jamul-Mufahras Li Al-Fazhil-Qur'an, (Bairut: Darul-Fikr, 1992)

Bellah, Robert N, Beyond Belief, Essay on Religion in a Post-Tradisional Word, (New York: Harper and Row, 1976)

Dahlan, Abdul Aziz, (et al), Ensiklopedia Hukum Islam, (Jakarta : PT Ichtiar Baru Van Hoeve, 1999)

Garaudy, Roger, Janji-janji Islam, terj. (Jakarta : Bulan Bintang, 1982)

Gibb, H.AR., Aliran-aliran Modern Dalam Islam, terj. (Jakarta : Rajawali Press, 1990)

Hasan, Muhammad Kamal, Prof., Muslim Intellectual Responses to New Order Modernization in Indonesia, (Kuala Lumpur : Dewan Bahasa dan Pustaka, 1980)

Hidayat, Komaruddin, Wahyu di Langit Wahyu di Bumi, (Jakarta: Paramadina, 2003)

Iqbal, Mohammad, The Recontruction of Relegius Thought in Islam, (Lahore: Ashraf, 1982)

Ismail, A. Ilyas, Dr. MA dan Hotman, Prio, MA. Filsafat Dakwah; Rekayasa Membangun Agama dan Peradaban Islam, (Jakarta : Prenada Media Kencana Press, 2011), Cet. ke-1.

Ka'bah, Rifyal, (et.al), Reaktualisasi Ajaran Islam : Pembaruan Agama Visi Modernis dan Visi Salaf, (Jakarta : Penerbit Minaret, 1987)

Kallaf, Abdul Wahab, Ringkasan Sejarah Perundangan Islam, terj. (kota Bharu : Pustaka Aman Press, 1971)

Kaloti, Sami Abdullah, The Reformation of Islam and The Impact of Jamaluddin al-Afghani and Muhammad Abduh on Islamic Education. Desertasi Ph. D., Marquettes University, 1974.

Karmi, Hasan Said, al-Manar and English-Arabic Dictionary, (Bairut: Longman Libraise Du Liban, 1970)

Madjid, Nurcholish, Islam Doktrin dan Peradaban, (Jakarta: Paramadina, 1992)

Maliki, Zainuddi, Agama Priyayi (Yogyakarta: Pustaka Marwa, 2004)

Manheim, Karl, "Conservative Though", dalam K. Mannheim, Essays on Sociology and Social Psycology, (London : Rautledge \& Kegan Paul, 1966) 
Nata, Abuddin, Peta Keragaman Pemikiran Islam di Indonesia, (Jakarta : Raja Grafindo Persada, 2001)

Noah Webstar, Webstar new International Dictionary of the English Language Unabridged (Massachusetts, USA: G\&C, 1966)

Rahman, Fazlur, "Islamic Modernism; Its Scope, Method, and Alternative", International Journal of Middle East Studies (1970)

Ramdhun, Abdul Baqi, Jihad Jalan Kami, (Solo : Era Intermedia, 2002)

Sharabi, Hisham, Arab Intellectuals and the West : The Formative Years 18751914, (Baltimore \& London : The John Hopkins University Press, 1970)

Shalaby, Ahmad, Masyarakat Islam, terj. (Singapura: Pustaka Nasional, 1966)

Shamsuddin, Abdul Ghani Hj., Tajdid dalam Pendidikan dan Masyarakat, (Kuala Lumpur : Persatuan Ulama Malaysia, 1989)

Shihab, Quraish, Membumikan Al- Qur'an, (Bandung: Mizan, 1993) ,Wawasan Al-Qur'an, (Bandung : Mizan, 1996), Cet. ke-1

Stroumsa, Sarah, Para Pemikir Bebas Islam, terj. (Yogyakarta: LKIS Yogyakarta, 2006), Cet. ke-1

Syakur, Amin, Dilema; Dakwah Kultural Versus Struktural, dalam Muhammad Sulthan; Menjawab Tantangan Zaman, Desain Ilmu Dakwah Kajian Ontologis, Epistemologis, dan Aksiologis, (Semarang: Walisongo Press dan Pustaka Pelajar, 2003)

Taufik, M. Tata, Dakwah Era Global, (kuningan, senin 27 Januari 2003)

Thahhan, Mahmud, Pembaruan Pemikiran Islam Sebuah Upaya Tipu Daya Belajar dari Kasus Sudan, terj. (Jakarta: Amarpress, 1987)

Trimingham, J. Spencer, Sufi Orders in Islam, (New York : Oxford University Press, 1973)

Watt, W.M, Islamic Philosophy and Theology, (Edinburgh : Edinburgh University Press, 1977)

Yatim, Badri, Sejarah Peradaban Islam, (Jakarta: Raja Grafindo Persada, 2003)

Yusuf, Amru, Istri Rasulullah Contoh dan Tauladan, (Jakarta : Gema Insani Press, 1997), Cet. ke- 1

Zon, Fadli, Sosok Ronggowarsito di Pentas Politik dan Seni Budaya Jawa, Prisma, No. 4, Tahun XXI, 1992. 